\title{
Effect of Different Land Configuration Techniques on Fusarium Wilt of Pigeonpea (Cajanus cajan L.)
}

\author{
R.L. Sharma*, V.K. Swarnkar, Khirod Barik and M.K. Sahu \\ Krishi Vigyan Kendra, Raipur, India \\ Indira Gandhi Krishi Vishwavidyalaya, Raipur, 492012 Chhattisgarh, India \\ *Corresponding author
}

\begin{tabular}{|c|}
\hline Keywords \\
\hline $\begin{array}{l}\text { Land configuration } \\
\text { techniques, Fusarium } \\
\text { wilt, Ridge and furrow, } \\
\text { Flat bed method, } \\
\text { Pigeonpea, Growth, Yield } \\
\text { attributes and yield }\end{array}$ \\
\hline Article Info \\
\hline $\begin{array}{l}\text { Accepted: } \\
\text { 24 September } 2018 \\
\text { Available Online: } \\
10 \text { October } 2018\end{array}$ \\
\hline
\end{tabular}

\section{Introduction}

India is major pulse growing country. The pulses are integral part of cropping system all over the country. Pulses are considered as lifeblood of agriculture because they occupy a unique position in every known system of farming as a main, catch, cover, green manure, intercrop, relay and mixed crop. It finds an important place in the farming systems adopted by small and marginal farmers in a large number of developing countries as it restores the soil fertility by fixing atmospheric
The present investigation was conducted during Kharif season of year 2017 at farmers' field of Raipur district of Chhattisgarh Plains to find out effect of different land configuration techniques on Fusarium wilt of pigeonpea as well as growth, yield and yield attributes of pigeonpea. All treatment had significant effect on wilt disease incidence, growth, yield, yield attributing characters like plant height, number of branches plant ${ }^{-1}$, number of pods plant ${ }^{-1}$, number of seeds pod $^{-1}, 100$ seed weight, seed yield, straw yield, harvest index and disease index. $T_{1}-$ Ridge and furrow method with 90 x $20 \mathrm{~cm}$ spacing resulted in lower wilt incidence at 60 DAS (2.90 per cent) and 150 DAS (9.18 per cent), higher plant height $(182.98 \mathrm{~cm})$, number of branches plant ${ }^{-1}(17.97)$, number of pods plant $^{-1}$ (147.67), number of seeds pod ${ }^{-1}(3.55), 100$ seed weight (10.24 g), seed yield (16.91 $\left.\mathrm{q} \mathrm{ha}^{-1}\right)$, straw yield $\left(44.31 \mathrm{q} \mathrm{ha}^{-1}\right)$ and harvest index (27.62 per cent), respectively and was found superior over rest of the treatments, which was followed by $\mathrm{T}_{2}$ - flat bed method of spacing $90 \times 20 \mathrm{~cm}$ and $\mathrm{T}_{3}$ - flat bed method of spacing $60 \times 20 \mathrm{~cm}$. The maximum wilt incidence at 60 DAS and 150 DAS was associated with crop sown broadcasted (8.36 and 30.93 per cent, respectively). Also, the minimum value of all above growth, yield and yield attributing characters was recorded with control plot i.e. broadcast method. 
largest area under cultivation of pulses, productivity is far lower than that of developed countries like China. United Nations organization (UNO) has also declared 2016 as International Year of Pulses to increase the overall productivity of pulses around the globe.

Pigeon pea, commonly known as redgram or tur or arhar [Cajanus cajan (L.) Millsp.], is the second most important pulse crop after chickpea in India. It is one of the important legume crops of tropics and subtropics and cultivated since prehistoric times and grown throughout the tropical and subtropical regions of the world between $30^{\circ} \mathrm{N}$ and $35^{\circ} \mathrm{S}$ latitudes. However, major area under pigeonpea in India is lying between $14^{0} \mathrm{~S}$ and $28^{0} \mathrm{~N}$ latitudes (Anonymous, 2011). Among the pulses it is extensively used as an important source of protein in human diet. Pigeonpea grain contains 23.3 per cent protein, 3.5 per cent minerals, and 57.6 per cent carbohydrates and provides $335 \mathrm{cal}$ energy per $100 \mathrm{~g}$ (Anonymous, 1981). Pigeon pea has multiple uses, besides its consumption in the form of dry split dhal the tender green seeds are used as vegetables and the stem and roots as fuel wood. In addition, it is also used for forage purpose and improves soil health through its deep strong rooting system, leaf drop at maturity and addition of nitrogen by symbiotic activities during the crop growth. Pigeonpea being an important nitrogen fixing crop can fix atmospheric $\mathrm{N}$ up to $200 \mathrm{~kg} \mathrm{~N} \mathrm{ha}{ }^{-}$ ${ }^{1}$ (Anonymous, 2010), Hence, pigeonpea is often called as "Biological plough". Extensive ground cover by pigeonpea prevents soil erosion by wind and water, encourages infiltration of rain water and smothers the weeds.

In India, the area under pigeonpea during 2016-17 was 5338 thousand hectares with production of 4873 thousand tonnes and average productivity of $913 \mathrm{~kg} \mathrm{ha}{ }^{-1}$
(Anonymous, 2017 a). Generally, Pigeonpea is grown in almost all states of India, but it is cultivated extensively in Bihar, Uttar Pradesh, Maharashtra, Tamil Nadu, Andhra Pradesh, Karnataka, West Bengal, Gujarat and Chhattisgarh. The total geographical area of Chhattisgarh is $13.8 \mathrm{~m}$ ha of which $5.9 \mathrm{~m}$ ha area is under gross cultivation. Pigeonpea occupies 66.20 thousand ha with production of 39.6 thousand tones. The average productivity of Pigeonpea in Chhattisgarh is $598 \mathrm{~kg} \mathrm{ha}^{-1}$ (Anonymous, 2017 b).

There are several constraints in pigeonpea which affects the productivity of the crop, one of them is diseases, which often pose serious problem. The diseases of economic importance at present are viz., Fusarium wilt, Sterility Mosaic Disease (SMD), Phytophthora Blight (PB), Macrophomina root rot, Stem canker, Alternaria blight and pearly cyst nematode. Among these diseases, the wilt is one of the major constraints, followed by Phytophthora blight and Sterility mosaic in the district, which is affecting the productivity of this crop per unit area.

The wilt is caused by Fusarium udum is one of most serious and oldest known disease and it is known to cause heavy losses every year in India (Kannaiyan et al., 1981). Fusarium wilt (Fusarium udum) is a soil borne disease. The genus Fusarium has wide host range and survives for long time in the field in the absence of host plant. Therefore, chemical control is not satisfactory, adequate and economical as a long-term solution. The frequent application of fungicides to the soil has caused environmental hazards causing water and soil pollution in addition to killing the non-target beneficial microorganisms in soil. Considering, the crop health and economic losses, the alternative to this is to explore land configuration techniques, which can be successfully adopted in modern agriculture. Keeping this in view, present 
investigation was envisaged with the management of wilt disease of pigeonpea by different land configuration techniques.

\section{Materials and Methods}

The present study was conducted during Kharif season of year 2017 at farmers field of Bemta village of Tilda block at Raipur district. This experiment was laid out in Randomized Block Design with six numbers of replications. The soil of the farmers' field was sandy loam in texture, neutral in reaction and had low nitrogen and medium phosphorus and potassium contents. Treatment consisting of ridge and furrow method $(90 \times 20 \mathrm{~cm})$, flat bed method $(90 \times 20 \mathrm{~cm})$, flat bed method $(60$ $\mathrm{x} 20 \mathrm{~cm}$ ) was tested during experimentation against broadcasting as control plot. Medium duration variety "Asha" was grown as a test crop. The duration of variety is 160-190 days with production potential of $16-18 \mathrm{q} \mathrm{ha}^{-1}$. The crop was sown as per treatments mentioned above, after onset of monsoon using a certified seed with seed rate of $20 \mathrm{~kg} \mathrm{ha}^{-1}$. To prevent the crop from soil and seed borne diseases, the seeds were treated with rhizobium, PSB and Thiram. The crop was fertilized with 20, 60 and $30 \mathrm{~kg} \mathrm{~N}, \mathrm{P}_{2} \mathrm{O}_{5}$ and $\mathrm{K}_{2} \mathrm{O}$ ha $^{-1}$, respectively as basal dose. The harvesting was done manually with the help of sickle, when the crop attained full maturity. The produce of a square meter from four randomly selected place of each plot was tied into bundle and allowed to sun drying in respective plots. The harvested bundles were weighed with the help of balance and transported to threshing floor. Threshing of produce of each plot was done separately by beating with wooden sticks; the seeds were then cleaned manually and weighed.

The plant height was measured from ground level upto growing tip of plant at harvest from four randomly selected one square meter place and then average was worked out. The number of branches plant ${ }^{-1}$, number of pods plant ${ }^{-1}$, number of seeds pod $^{-1}$ were counted at harvest from one square meter randomly selected spot and the mean number were computed. A random sample for 100 seeds was taken from the seeds produce, counted and its weight was recorded. Seed yield of a square meter from four randomly selected place of each plot was noted down, after threshing, winnowing and drying and calculated in $\mathrm{q} \mathrm{ha}^{-1}$. Straw yield was obtained by deducting the seed yield from the weight of total dry produce (biological yield) of respective plot and calculated in $\mathrm{q} \mathrm{ha}{ }^{-1}$. The figure of biological yield was calculated by summing seed yield and straw yield. Finally it was converted on hectare basis.

Harvest Index is the ratio of economic yield to the total biological yield. Harvest index reflects the proportion of assimilate distribution between economical and total biomass. It is computed by the following formula.

Economical yield $\left(\mathrm{q} \mathrm{ha}^{-1}\right)$ Harvest Index (HI) \% = ---------------- X 100

Biological Yield (q ha $\left.{ }^{-1}\right)$

Biological yield $=$ seed yield + straw yield

Wilt incidence per cent (WI \%) is calculated at 60 DAS and 150 DAS, with the help of following formulae:

Number of Plants infected by wilt disease Wilt incidence (WI) \% = ------------- X 100

Total Number of plants observed

Disease index indicate the reduction in yield of crop due to disease attack and is expressed in per cent by using formulae:

Yield from best treated plot-

Yield from untreated plot

Disease index $(\%)=$----------------------- X 100

Yield from best treated plot 


\section{Results and Discussion}

Different land configuration practices for management of Fusarium wilt of pigeonpea had significant effect on plant height, number of branches plant ${ }^{-1}$, wilt disease incidence (\%), number of pods plant ${ }^{-1}$, number of seeds $\operatorname{pod}^{-1}$, test weight ( $\mathrm{g}$ ), seed yield, straw yield, harvest index and disease index during the year of experimentation (Table 1 and 2).

\section{Effect on plant height (cm)}

Among different land configuration practices for pigeonpea cultivation have significant effect on length of plants and were presented in Table 1. Cultivation of pigeonpea with Treatment $\mathrm{T}_{1}$ - Ridge and furrow method $(90 \mathrm{x}$ $20 \mathrm{~cm}$ ) produced longer plants of $182.98 \mathrm{~cm}$ during experimentation and was found significantly superior over other land configuration practices, followed by $\mathrm{T}_{2}$ - flat bed method of spacing $90 \times 20 \mathrm{~cm}(175.38$ $\mathrm{cm})$ and $\mathrm{T}_{3}$ - flat bed method of spacing $60 \mathrm{x}$ $20 \mathrm{~cm}(173.03 \mathrm{~cm})$ during experiment, respectively and both $T_{2}$ and $T_{3}$ was found at par results with each other.

Pandey et al., (2014) also reported almost similar results, indicating that higher values of growth attributes of pigeonpea was found with raised bed as compare to flat bed. The results also fall in line with the findings of Idapuganti et al., (2007), Kalokhe (2010), Sathe (2015) and Kumar et al., (2012). The shortest plant height was obtained under broadcasting method $(155.36 \mathrm{~cm})$.

\section{Effect on number of branches plant ${ }^{-1}$}

The data on number of branches plant ${ }^{-1}$ under various land configuration treatments was presented in Table 1. Results reveal that all the treatments differ statistically significant from each other. However, the highest number of branches plant ${ }^{-1}$ (17.97) was found with crops sown with ridge and furrow $(90 \times 20 \mathrm{~cm})$ method and was found superior over any other treatments, followed by $\mathrm{T}_{2}$ - flat bed method with spacing $90 \times 20 \mathrm{~cm}$ (16.26) and $\mathrm{T}_{3}$ - flat bed method with spacing $60 \times 20 \mathrm{~cm}(14.60)$ during experiment year, respectively. The lowest number of branches plant ${ }^{-1}$ was obtained with crop sown with broadcasting (12.75).

These results confirm the findings of Kalokhe (2010) in which he conducted an experiment to study the effect of land configurations, biofertilizers and reported that growth parameters viz., plant height, number of leaves, leaf area, number of branches and total dry matter production was significantly higher in ridges furrow as compared to flat bed planting.

This report was supported by Pandey et al., (2014), Kantwa et al., (2006), Idapuganti et al., (2007), Kumar et al., (2012). Sathe (2015) also reported that significantly higher plant height, more number of functional leaves, more leaf area, number of branches and dry matter production in ridges furrow as compared to flat bed planting.

\section{Effect on wilt incidence (\%)}

The data on wilt disease incidence per cent under various treatments have been presented in Table 1. Results reveal that all the treatments significantly differ from each other. However, the lowest wilt disease incidence per cent (2.90) at 60 DAS was noticed with treatment $\mathrm{T}_{1}$-Ridge and furrow method $(90 \mathrm{x}$ $20 \mathrm{~cm}$ ), and was found significantly superior over rest of the treatments, followed by $\mathrm{T}_{2}-$ Flat bed method with spacing of $90 \times 20 \mathrm{~cm}$ (3.71 per cent) and $T_{3}-$ Flat bed method with spacing of $60 \times 20 \mathrm{~cm}$ (5.04 per cent) during experimental year, respectively. The highest wilt incidence was obtained with control plot i.e. 8.36 per cent. 
As far as wilt incidence per cent at 150 DAS is concerned, similar results were obtained. Treatment $\mathrm{T}_{1}-$ Ridge and furrow method ( 90 x $20 \mathrm{~cm}$ ) recorded lowest wilt incidence per cent (9.18), followed by $\mathrm{T}_{2}-$ Flat bed method with spacing $90 \times 20 \mathrm{~cm}$ (14.08 per cent) and $\mathrm{T}_{3}$ - Flat bed method with spacing $60 \times 20 \mathrm{~cm}$ (17.36 per cent). The highest wilt incidence was obtained with control plot (30.93 per cent). All the treatments were found statistically significant from each other.

These results confirms the findings of Ahlawat et al., (2005) in which they reported that the management options include providing effective drainage by altered land configuration and post-waterlogging $\mathrm{N}$ fertilization reduce the incidence of wilt disease.

The advantage of planting on ridges (ICRISAT, 1989) or on broad bed (2.5 m) and furrows (Desai et al., 2000) has been well established and is being increasingly adopted by farmers.

\section{Effect on number of pods plant ${ }^{-1}$}

As far as data on number of pods plant ${ }^{-1}$ is concerned, all the treatments regarding land configuration practices of pigeonpea cultivation differ significantly with each other and was presented in Table 1.

Results revealed that, highest number of pods plant $^{-1}$ (147.67) was recorded in crops sown with ridge and furrow $(90 \times 20 \mathrm{~cm})$ method and was found superior over any other treatments, followed by $\mathrm{T}_{2}$ - flat bed method with spacing $90 \times 20 \mathrm{~cm}(130.35)$ and $\mathrm{T}_{3}$ - flat bed method with spacing $60 \times 20 \mathrm{~cm}$ (118.86). The lowest number of pods plant ${ }^{-1}$ was obtained with $\mathrm{T}_{4}$ - broadcasting (92.35).

Pandey et al., (2014) also reported similar results in which they stated that significantly higher yield attributes like number of pods plant $^{-1}$ and seed yield of pigeonpea was found superior with raised bed as compare to flat bed.

The results are in confirmation with Kantwa et al., (2005), in which they conducted the experiment on effect of land configuration on performance of pigeonpea and reported that BBF improved the yield attributes (pods/plant and seeds/pod) of pigeonpea over flat planting Kantwa et al., (2006), Idapuganti et al., (2007) also finds similar results.

\section{Effect on number of seeds pod ${ }^{-1}$}

Various land configuration practices has a significant effect on number of seeds pod $^{-1}$ of pigeonpea (Table 1). Highest number of filled seeds pod $^{-1}$ (3.55) was recorded with crop sown in ridge and furrow $(90 \times 20 \mathrm{~cm})$ method and was found statistically superior over any other land configuration practices.

However, this treatment was found statistically at par results with crop sown with $\mathrm{T}_{2}$ - flat bed method with spacing $90 \times 20 \mathrm{~cm}$ (3.43), followed by $\mathrm{T}_{3}$ - flat bed method with spacing $60 \times 20 \mathrm{~cm}$ (3.21). The lowest number of seeds pod ${ }^{-1}$ was obtained with pigeonpea sowing with broadcast (3.0).

The result are in confirmation with Kantwa et al., (2005) reported that BBF improved the yield attributes (pods/plant and seeds/pod) of pigeonpea over flat planting.

\section{Effect on 100 seed weight $(\mathrm{g})$}

In regard with effect of different land configuration techniques for pigeonpea cultivation on 100 seed weight, heavier seeds (10.24 g) was associated with crop sown in ridge and furrow (90 x $20 \mathrm{~cm})$ method and was found significantly superior over any other treatments and was presented in Table 1. 
Table.1 Effect of different land configuration techniques on pigeonpea wilt, growth and yield attributes

\begin{tabular}{|c|c|c|c|c|c|c|c|}
\hline \multirow[t]{2}{*}{ Treatments } & \multirow{2}{*}{$\begin{array}{c}\text { Plant } \\
\text { Height }(\mathbf{c m})\end{array}$} & \multirow{2}{*}{$\begin{array}{c}\text { Number of } \\
\text { Branches } \\
\text { Plant }^{-1}\end{array}$} & \multicolumn{2}{|c|}{ Wilt Incidence (\%) } & \multirow{2}{*}{$\begin{array}{c}\text { Number } \\
\text { of Pods } \\
\text { Plant }^{-1}\end{array}$} & \multirow{2}{*}{$\begin{array}{l}\text { Number } \\
\text { of Seeds } \\
\text { Pod }^{-1}\end{array}$} & \multirow{2}{*}{$\begin{array}{l}100 \text { Seed } \\
\text { Weight } \\
(\mathrm{g})\end{array}$} \\
\hline & & & 60 DAS & 150 DAS & & & \\
\hline $\begin{array}{l}T_{1}-\text { Ridge and Furrow method }(90 \mathrm{x} \\
20 \mathrm{~cm})\end{array}$ & 182.98 & 17.97 & 2.90 & 9.18 & 147.67 & 3.55 & 10.24 \\
\hline $\mathrm{T}_{2}-$ Flat bed method $(90 \times 20 \mathrm{~cm})$ & 175.38 & 16.26 & 3.71 & 14.08 & 130.35 & 3.43 & 10.08 \\
\hline$T_{3}-$ Flat bed method $(60 \times 20 \mathrm{~cm})$ & 173.03 & 14.60 & 5.04 & 17.36 & 118.86 & 3.21 & 9.28 \\
\hline$\overline{T_{4}-\text { Broadcasting }}$ & 155.36 & 12.75 & 8.36 & 30.93 & 92.35 & 3.0 & 9.03 \\
\hline SEm \pm & 1.39 & 0.51 & 0.17 & 0.52 & 2.87 & 0.04 & 0.60 \\
\hline $\mathrm{CD}(\mathrm{P}=0.05)$ & 4.19 & 1.52 & 0.50 & 1.56 & 8.66 & 0.13 & 0.18 \\
\hline
\end{tabular}

Table.2 Effect of different land configuration techniques on pigeonpea seed yield, straw yield and harvest index

\begin{tabular}{|c|c|c|c|c|c|}
\hline Treatments & $\begin{array}{l}\text { Seed Yield (q } \\
\left.\qquad \mathrm{ha}^{-1}\right)\end{array}$ & $\begin{array}{l}\text { Straw Yield } \\
\qquad\left(\mathbf{q} \mathrm{ha}^{-1}\right) \\
\end{array}$ & $\begin{array}{l}\text { Biological Yield } \\
\qquad\left(\mathbf{q} \mathrm{ha}^{-1}\right) \\
\end{array}$ & $\begin{array}{l}\text { Harvest Index } \\
\qquad(\%) \\
\end{array}$ & $\begin{array}{c}\text { Disease } \\
\text { Index }(\%) \\
\end{array}$ \\
\hline $\begin{array}{l}T_{1}-\text { Ridge and Furrow method }(90 \times 20 \\
\mathrm{cm})\end{array}$ & 16.91 & 44.31 & 61.22 & 27.62 & - \\
\hline $\mathrm{T}_{2}-$ Flat bed method $(90 \times 20 \mathrm{~cm})$ & 14.15 & 39.88 & 54.03 & 26.18 & 16.32 \\
\hline$T_{3}-$ Flat bed method $(60 \times 20 \mathrm{~cm})$ & 12.74 & 38.46 & 51.20 & 24.88 & 24.66 \\
\hline $\mathrm{T}_{4}-$ Broadcasting & 6.95 & 31.42 & 38.37 & 18.11 & 58.90 \\
\hline SEm \pm & 0.32 & 1.15 & 0.55 & - & - \\
\hline $\mathrm{CD}(\mathrm{P}=0.05)$ & 0.95 & 3.46 & 1.67 & - & - \\
\hline
\end{tabular}


However, this treatment was found statistically at par results with crop sown in $\mathrm{T}_{2}$ - flat bed method with spacing of $90 \times 20 \mathrm{~cm}$ $(10.08 \mathrm{~g})$, which was followed by treatment $\mathrm{T}_{3}$ - flat bed method with spacing $60 \times 20 \mathrm{~cm}$ $(9.28 \mathrm{~g})$. The lighter seed was obtained with pigeonpea sowing with broadcast $(9.03 \mathrm{~g})$.

Kumar et al., (2012) from Indian Agricultural Research Institute, New Delhi also found that, there is a significant improvement in yield attributes and yield components under BBF and Paired row planting over uniform row planting. Pandey et al., (2014) also find similar results and reported that significantly higher values of yield attributes and seed yield of pigeonpea was found with raised bed as compare to flat bed.

\section{Effect on Seed yield (q ha $\left.^{-1}\right)$}

Effect of different land configuration techniques for pigeonpea cultivation on seed yield was presented in Table 2.

The results showed that all treatments differ significantly from each other. Treatment $\mathrm{T}_{1}-$ Ridge and furrow method $(90 \times 20 \mathrm{~cm})$ recorded statistically significant highest seed yield (16.91 q ha-1), and was found superior over rest other treatment techniques. $\mathrm{T}_{2}-$ flat bed method with spacing of $90 \times 20 \mathrm{~cm}$ recorded seed yield of $14.15 \mathrm{q} \mathrm{ha}^{-1}$, and was followed by treatment $\mathrm{T}_{3}$ - flat bed method with spacing $60 \times 20 \mathrm{~cm}\left(12.74 \mathrm{q} \mathrm{ha}^{-1}\right)$. On the other hand, the minimum seed yield was recorded under control plot (6.95 $\left.\mathrm{q} \mathrm{ha}^{-1}\right)$.

Same trends were also found by Pandey et al., (2014) and Kumar et al., (2012). The results was also confirms the findings of Desai et al., (2000) in which they noted the beneficial effect of land configuration on pigeonpea crop in vertisols and results revealed that significant effect of different land configuration on seed yield of pigeonpea.
Mishra et al., (2009) and Ram et al., (2011) also reported that the adoption of raised bed system resulted higher seed yield than ridge plus furrow and flat bed systems.

Mankar and Nawlakhe (2013) from Nagpur also concluded that opening of furrow in every row recorded maximum and significantly higher pigeonpea yield over opening furrow after every 2 and 3 rows and $27.3 \%$ more yield over flat bed.

The capacity of plants to produce seed yield depends not only on the size of photosynthetic systems, it's efficiently and length of time for which it is active but also on translocation of dry matter into economic sink. The final build-up of yield is cumulative function of yield components.

Higher seed yield under these treatments was due to the highest branches plant ${ }^{-1}$, pods plant $^{-1}$, seeds pod $^{-1}$ and seed weight, resulted in higher dry matter production, high growth in terms of LAI, which resulted in higher production of photosynthesis, which acts as a source and greater translocation of food materials to the reproductive parts resulted in superiority of yield attributing characters and ultimately high yield.

\section{Effect on straw yield (q ha $\left.{ }^{-1}\right)$}

As far as straw yield of pigeonpea under different land configuration techniques was concerned, highest straw yield (44.31 q ha ${ }^{-1}$ ) was associated with treatment $\mathrm{T}_{1}$ - Ridge and furrow method $(90 \times 20 \mathrm{~cm})$ and was found statistically superior over rest other treatments, followed by $\mathrm{T}_{2}-$ flat bed method with spacing $90 \times 20 \mathrm{~cm}\left(39.88 \mathrm{q} \mathrm{ha}^{-1}\right)$ and $\mathrm{T}_{3}$ - flat bed method with spacing $60 \times 20 \mathrm{~cm}$ (38.46 q ha ${ }^{-1}$ ). However, $\mathrm{T}_{2}$ and $\mathrm{T}_{3}$ was found statistically at par with each other. The lowest straw yield was recorded with control plot (31.42 q ha ${ }^{-1}$ ). Kantwa et al., (2006), Kalokhe 
(2010) and Sathe (2015) also find similar results.

\section{Effect on harvest index (\%)}

Harvest index reflects the proportion of assimilate distribution between economical and total biomass. Under different land configuration techniques for pigeonpea cultivation, maximum harvest index was recorded with crop sown with ridge and furrow method (27.62 per cent) followed by $\mathrm{T}_{2}$ - flat bed method with spacing $90 \times 20 \mathrm{~cm}$ (26.18 per cent) and $\mathrm{T}_{3}$ - flat bed method with spacing $60 \times 20 \mathrm{~cm}(24.88$ per cent), whereas minimum harvest index were registered under control plot $\mathrm{T}_{4}-$ broadcasting (18.11 per cent).

\section{Effect on disease index $(\%)$}

Disease index indicate the reduction in yield of crop due to disease attack. In regard with different land configuration techniques for management of pigeonpea wilt, the losses in pigeonpea yield was upto the tune of 16.32 to 58.90 per cent. Maximum losses in yield or disease index were noticed under control plot (58.90 per cent), whereas minimum disease index were registered under $\mathrm{T}_{2}-$ Flat bed method with spacing of $90 \times 20 \mathrm{~cm}$ (16.32 per cent) closely followed by $\mathrm{T}_{3}-$ Flat bed method with spacing of $60 \times 20 \mathrm{~cm}$ (24.66 per cent) in experimental year, respectively as compared to $\mathrm{T}_{1^{-}}$Ridge and furrow method $(90 \times 20 \mathrm{~cm})$.

On basis of ongoing experiment, it was concluded that sowing of pigeonpea in ridge and furrow method with spacing of $90 \times 20$ $\mathrm{cm}$ found to be effective and achieve higher seed yield, staw yield and yield attributing characteristics like plant height, number of branches plant ${ }^{-1}$, number of pods plant $^{-1}$, number of seeds pod $^{-1}, 100$ seed weight and harvest index than any other techniques.

\section{References}

Ahlawat I P S, Gangaiah B and Singh I P. 2005. Pigeonpea (Cajanus cajan) research in India: an overview. Indian Journal of Agricultural Sciences 75(6): $309-20$.

Anonymous, 1981. Food composition of pulses. Indian Farming 31(5): 41.

Anonymous, 2010. A profile, AICRP on Pigeonpea Indian Institute of Pulse Research, Kanpur.

Anonymous, 2011. Vision 2030, Indian Institute of Pulse Research, Kanpur.

Anonymous, 2017 (a). http://www.indiastat. com/table/agriculture-data/2/agricultural -production/225/17337/data.aspx.

Anonymous, 2017 (b). http://www.indiastat. com/table/agriculture-data/2/arhartur/19566/967651/ data.aspx.

Desai, N. C., Ardeshna, R.B. and Intwala, C. G. 2000. Increasing pigeonpea productivity by providing land configuration in vertisols. International chickpea and pigeonpea newsletter 7: 66-67

ICRISAT. 1989. Soil aeration effects. (In) ICRISAT Annual Report 1988. International Crops Research Institute for the Semi-Arid Tropics, Patancheru, Andhra Pradesh, India, p 86.

Idapuganti, K. G., Mankar P. S., Khawale, V. S., Date, C. P. and S. N. Gaindhane. 2007. Effect of land configuration and weed biomass addition on growth and yield of semi-rabi pigeonpea. Journal of soils and crops 17 (1): 114-116

Jogdande, V., G.C. Malvi, S.R. Dalal and A.P. Karunkar. 2003. Effect of different layouts and nitrogen levels on growth and yield of soybean pkv, Research Journal 27(2): 183-184.

Kalokhe, K.T. 2010. Effect of biofertilizers on pigeonpea under different land configuration. M.Sc. (Agri.) Thesis, VNMKV, Parbhani (M.S.) India. 
Kannaiyan, J., Nene, Y.L. and Reddy, M.V. (1981). Influence of wilt at different growth stages on yield loss in Pigeonpea. Tropical Pest Management 27: 141 .

Kantwa, S.R., Ahlawat, I.P.S. and B. Gangaiah. 2005. Effect of land configuration, post-monsoon irrigation and phosphorus on performance of sole and intercropped pigeon pea (Cajanus cajan L.). Indian Journal of Agronomy 50 (4): 278-280.

Kantwa, S.R., I.P.S. Ahlawat and B. Gangaiah. 2006. Performance of sole and intercropped pigeonpea (Cajanus cajan) as influenced by land configuration, post- monsoon irrigation and phosphorous fertilization. Indian Journal of Agricultural Sciences 76(10):635637.

Kumar, P., K.S. Rana and D.S. Rana. 2012. Effect of planting systems and phosphorous with bio-fertilizers on the performance of sole and intercropped pigeonpea (Cajanus cajan) under rainfed conditions. Indian Journal of Agronomy 57(2):127-132.

Lal, S., Brahm Prakash and Sushila Srivastava, 1996, Current trends in pulse production in India. Indian Farming 11(1): 11-14.
Mankar, D.D. and S.M. Nawlakhe. 2013. Effect of land configuration and phosphate management on growth and yield of semi-rabi pigeonpea. Crop Research 46 (1, 2 \& 3): 84-87.

Mishra, P.K., Vasudeva Reddy, Ch and U. Satish Kumar, 2009. An evaluation of furrows for managing soil and water loss from shallow alfisols under simulated rainfall. Soil Use and Management 24: 171-180

Pandey, I.B., Tiwari, S., Pandey, R. K. and Rakesh Kumar. 2014. Effect of bed configuration, fertilizer levels and placement method on the productivity of long duration pigeonpea under rainfed condition. Journal of Food Legume 27(3): 206-209

Ram Hari Singh G, Aggrawal N and Kaur J. (2011). Soybean growth, productivity and water use under different sowing methods and seeding rates in Punjab. Indian Journal of Agronomy 56 (4):377380.

Sathe, R.K. 2015. Response of transplanted pigeonpea to different panting geometry and land configuration. M.Sc. (Agri.) Thesis, VNMKV, Parbhani (M.S.) India.

\section{How to cite this article:}

Sharma, R.L., V.K. Swarnkar, Khirod Barik and Sahu, M.K. 2018. Effect of Different Land Configuration Techniques on Fusarium Wilt of Pigeonpea (Cajanus cajan L.). Int.J.Curr.Microbiol.App.Sci. 7(10): 3237-3245. doi: https://doi.org/10.20546/ijcmas.2018.710.375 